\title{
Climate Change Impacts, Vulnerability, and Adaptation Options among the Lozi Speaking People in the Barotse Floodplain of Zambia
}

\author{
Milupi, I. $D^{1^{*}}$, Njungu, $M^{2}$, Moonga, S. M. ${ }^{1}$, Namafe, C. M. ${ }^{1}$, Monde, P. $^{1}$, Simooya, S. $M^{1}$ \\ ${ }^{I}$ The University of Zambia, School of Education, Department of Language and Social Sciences Education. P.O \\ BOX 32379, Lusaka, Zambia \\ ${ }^{2}$ University of Waterloo, School of Public Health and Health Systems, LHN 2717,200 University Avenue West, \\ Waterloo, Canada
}

*Corresponding Author: Milupi, I. D, The University of Zambia, School of Education, Department of Language and Social Sciences Education. P.O BOX 32379, Lusaka, Zambia

\begin{abstract}
The aims of this study were: - to find out how communities in the Barotse floodplain of Mongu district in Zambia are affected by climate change, establish adaptation opportunities practiced by the Lozi people and to raise awareness and stimulate interest in matters of climate change. Using primary and secondary data sources, it was observed that the negative impacts of climate change among the Lozi people include; increase in atmospheric pressure and excessive heat and flooding, prolonged spells of unexpected changes in seasons, reduction in food production and security, as well as inadequate clean water supply and extinction of some plant and animal species. The study also revealed vast local ecological knowledge that, if utilised, may help in the adaptation of climate change. The study further showed that climate change awareness and education are key in mitigating and adapting to climate change effects, though it was not found in the area. The study strongly recommend regular climate change awareness activities in order to promote mitigation and adaptation, need to pay greater and particular attention to the vast local ecological knowledge exhibited by the Lozi people that would help in adaptation to climate change in the area.
\end{abstract}

Keywords: Adaptation; Barotse floodplain; climate change; impacts; mitigation; vulnerability; Zambia

\section{INTRODUCTION}

Climate change according to National Policy on Climate Change (NPCC), (2016) is a change of climate attributed directly or indirectly to human activities observed over comparable periods of climatic change time. Additionally climate change according to Intergovernmental Panel on Climate Change (IPCC), (2007a) is any change in climate over time, whether due to natural variability or and as a result of human activity. Climate change is widely recognised as a major challenge facing humanity. Adverse effects of climate change continue to be a major threat to rural livelihoods (IPCC, 2007a, 2007b; Nhemachena, 2009; Pouliotte et al., 2009; McSweeney, and Lizcano, G. (2010). This poses a challenge of developing innovative technologies to improve rural livelihoods and environmental conservation and ensuring adoption of such technologies (Nyanga et al., 2011).

Education plays a critical role in supporting climate change adaptation and mitigation (UNESCO, 2009). This is because through education, people's mindsets change positively. Climate change education is about helping society to understand and address the impacts of global warming today, while at the same time encouraging the change in attitudes and behaviour needed to put our world on a more sustainable path in the future (UNESCO, 2009).

It is education that helps people to change from critical thinking to critical action. Furthermore, Education contributes to the provision of skills and capacities and also shapes the values, attitudes and behaviours needed to put the world on a more sustainable path. Such contributions made by education make it possible for communities to find ways of adapting to the effects of climate change. Education also introduces people to practical and successful actions that other groups and communities have or are undertaking to mitigate or adapt to climate change (Nicholls, 2016). 
In Zambia, Climate change has emerged as one of the most pressing issues affecting socio economic development (MLNREP, 2016). This is because Zambia is already experiencing climate induced hazards, which include drought and dry spells, seasonal and flash floods and extreme temperatures (MLNREP, 2016).The impacts of climate change in Zambia extend to wildlife and biodiversity (MTENR 2010; Oxfam, 2015). For example, forests which previously regenerated quickly have been slower to recover due to the heat and drought impacts of climate change(Oxfam, 2015).Climate change in Zambia is already affecting most of the rural poor (Oxfam,2015). For example, floods are gradually increasing in frequency and intensity especially in regions around the Zambezi River (Oxfam, 2015). Droughts destroy crops, and also cause siltation and sedimentation in rivers and streams there by reducing their capacity to hold water. These climate change effects have led to the introduction of climate change into Zambian development policies such as urban planning and national development strategies (Romdhani et al., 2018).

In this paper, we aim to find out how communities in the Barotse floodplain of Mongu district are affected by climate change, establish adaptation opportunities practiced and to raise awareness in order to stimulate interest in matters of climate change among the Lozi people.

\subsection{Description of Study Area}

The Barotse floodplain also known as the Bulozi Plain, Lyondo or Zambezi floodplain is one of Africa's great wetlands (GRZ 2014).It is the second largest wetland in Zambia after the Lake Bangweulu (GRZ, 2014). It is located in the western province of Zambia and is 600km west of Zambia's capital city Lusaka. The Barotse floodplain is a vast wetland along the upper Zambezi River near the border with Angola (Figure 1). The region is one of Africa's great wetlands with an extent of some $230 \mathrm{~km}$ from north to south (GRZ, 2014). Its width is mostly about $30 \mathrm{~km}$ though it reaches a width of $50 \mathrm{~km}$ in some areas. Peak water levels occur in April and begin receding from May to July (GRZ 2014). During November when water levels are lowest, the region still contains many lagoons, swamps, and channels (GRZ, 2014). The floodplain is just south of the remote Liuwa National Park, where great concentrations of wildlife occur. The Zambezi River crosses the area from North to South. The sub-basin is fed by high annual rainfall of up to $1400 \mathrm{~mm}$ (GRZ 2014). As the area is very flat, the Zambezi water floods the plain 3 to 5 months per year, from January to June (GRZ, 2014).

The Lozi people are the inhabitants of the Barotse floodplain, and derive various livelihoods from the floodplain such as fish and crop planting as water recedes during dry season. The traditional authority of the area is the "Barotse Royal Establishment" (BRE). This institution isled by the King, the Litunga (Owner of the Land) who is assisted by the ministers locally called Indunas. The Barotse is famous for its cultural heritage, and in particular for the Kuomboka ceremony, when the Litunga leaves his flood capital, Lealuiin the plain to go to his mound palace of Limulungaon the upper land. The Kuomboka ceremony is an annual relocation of people, their cattle and the Litunga. It is a highlycelebrated traditional ceremony (Nkhata and Kalumiana, 1997). "Kuomboka"is a silozi word which means coming out of water. The Barotse floodplain is flanked by plateaux of Kalahari sand covered in semi- evergreen woodland, interspersed with low lying dambos which are characterised by grassland vegetation (Timberlake, 1997). The Liuwa Plain National Park and associated areas to the north west of the floodplain are relatively flat, and are waterlogged during the rainy season while remaining extremely dry during the rest of the year (Simwinji, 1997).

The ecological characteristics and conditions of the Barotse floodplain, and the human production systems it supports, depend largely on the timing and duration of the annual floods (Timberlake, 1997).Agriculture is the backbone of most people in the Barotse floodplain, especially in rural communities (Baidu - Forson et al., 2014). According to Turpie et al., (1999), about 90 percent of the population in Barotse floodplain is involved in agriculture, mostly for subsistence. According to Simwinji, (1997) and Baidu -Forson et al., (2014), the total agricultural land in Western Province is estimated at 279,000hectares. Mongu East and the Borotse floodplains are the main agricultural production areas (Simwinji, 1997).The agricultural economy of the Borotse floodplain involves a strong interaction between herding, cropping and fishing activities (Simwinji, 1997).

Crops grown in the Barotse floodplain area include rice (Oryza spp.), which is grown on lower areas in the plain locally called ("litapa"); maize (Zea mays), grown on raised mounds locally called ("mazulu"), and cassava (Manihote esculenta) grown on the upland areas. Maize is the preferred crop 
on lowlands after the rains or on "mazulu" landforms during the rainy season (Baidu -Forson et al. 2014). Maize is planted on fields in the floodplain and on good upland soils, while poorer fields are generally cropped with sorghum (Sorghum bicolor), millet (Panicum miliaceum) and cassava.

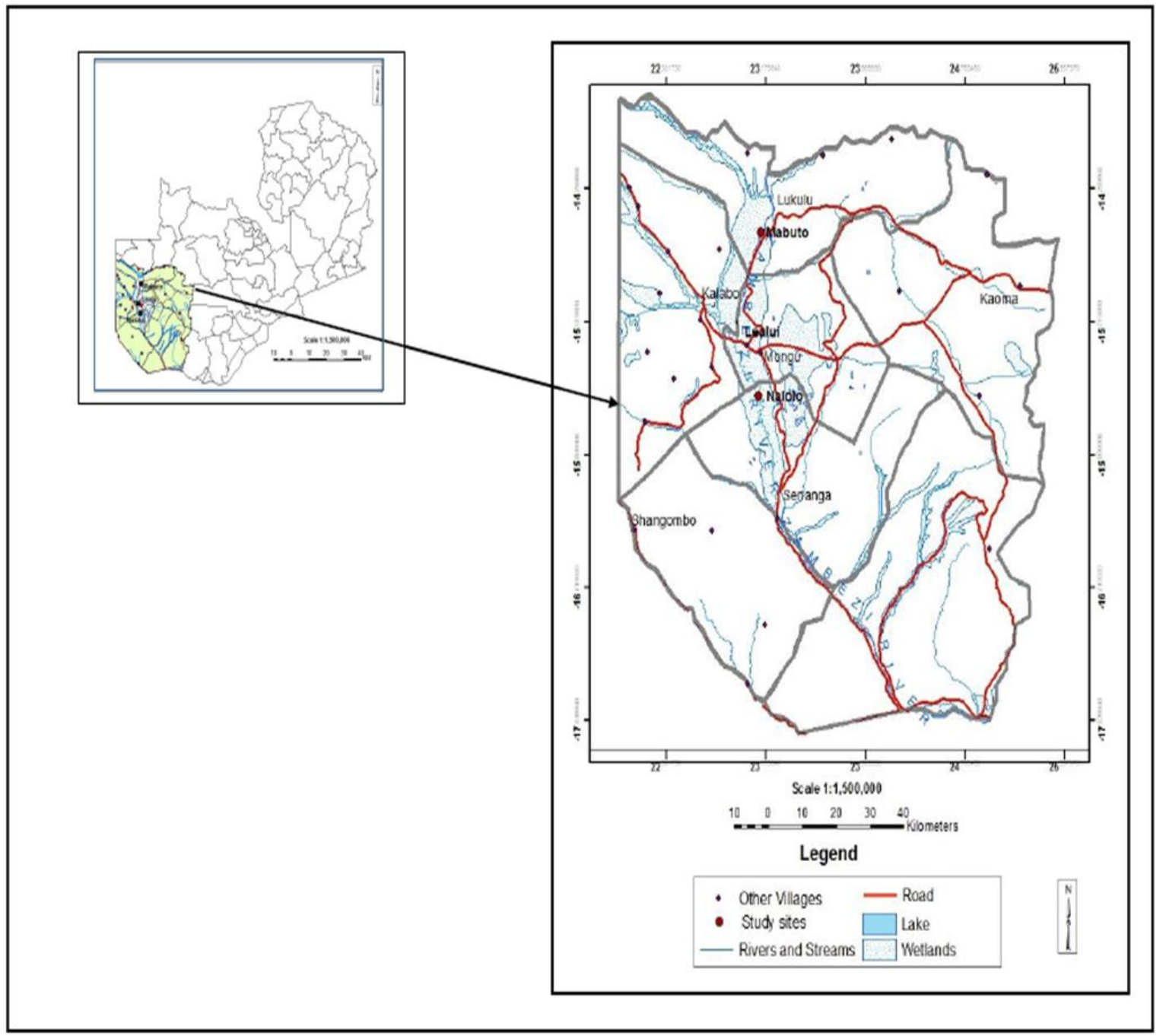

Figure1: Map of Zambia showing the location of Barotse floodplain

\section{MATERIALS AND MethodS}

The study was based on secondary and primary data collected in June 2019. Secondary data were derived from published materials and policy documents, whereas primary data were collected through an ethnographic method namely household survey. Secondary data analysis provided a better understanding of climate change impacts, mitigation and adaptation measures. In the current study, journal papers, National policy on climate change, and government records such as National Climate Change Response Strategy were examined. These documents provided background information for the research and allowed for assessment of the suitability of the project before conducting interviews (Owen, 2014).

\subsection{Household Surveys}

The household surveys used in the study generated quantitative and qualitative data through the structured, researcher-administered questionnaires, which comprised both closed and open-ended questions. The sampling unit for the Barotse floodplain was the household with the target respondent being the household head. Households were randomly selected. In total 22 household heads from Barotse floodplain were interviewed. Both men and women were interviewed during the survey. Of the respondents interviewed in Barotse floodplain, 13 were females while men were 9.Sixteen villages namely, Laelui, Liyolelo, Mabuto, Mutalaiti, Nambulu, Nena, Nalolo, Nkhanda, Maala, Ng'umbili, Siyubo, Masheye, Likundu, as well as Nanikelako, Malamunga and Nalongo were were covered in 
Climate Change Impacts, Vulnerability, and Adaptation Options among the Lozi Speaking People in the Barotse Floodplain of Zambia

Barotse floodplain. To ensure that the questionnaire was suited to the context, a pre-test was conducted at Mongu harbour in Mongu town.

The households were interviewed with regards to the following aspects regarding Climate change;

- The effects of climate change in Barotse floodplain;

- The adaptation practices of the local communities in Barotse floodplain; and

- Climate change education awareness activities taking place in Barotse floodplain

Quantitative data were coded and processed using Statistical Package for Social Sciences

(SPSS) software to generate the frequencies of the responses. Cross-tabulation of some variables was done to establish relationships between them. Below, we report the results of the study, highlighting the effects of climate change, adaptation measure and climate change awareness activities taking place in the Barotse floodplain.

\section{RESULTS AND DISCUSSION}

As reflected in Figure 2, most of the respondents (7) indicated that climate change is any changes that occur in one's life. Other respondents (7) connected climate change to low yields in agricultural products. Some of the respondents (7) believed climate change is flood while 2 related climate change to reduction in rainfall patterns. Only 1 out of the 22 respondents had no idea of what climate change is.

Table1: Respondents' responses on their understanding of the term climate change

\begin{tabular}{|l|l|}
\hline \multicolumn{1}{|c|}{ Response } & \\
\hline Change of life & 7 \\
\hline Low agricultural yields & 5 \\
\hline Floods & 7 \\
\hline Reduction in rainfall patterns & 2 \\
\hline No idea & 1 \\
\hline Total & $\mathbf{2 2}$ \\
\hline
\end{tabular}

Source: Field data 2019

\subsection{Causes of Climate Change}

Table 2 indicates the responses on the causes of climate change in Barotse floodplain. Understanding the causes of climate change is critical to the local communities in that it will benefit them on how to mitigate and adapt to the effects of climate change.

Table2: Responses regarding causes of climate change

\begin{tabular}{|l|l|}
\hline \multicolumn{1}{|c|}{ Response } & \\
\hline Lack of rainfall & 15 \\
\hline Excessive rainfall & 2 \\
\hline Deforestation & 2 \\
\hline Excessive heat & 1 \\
\hline Water pollution by sprit of the river & 1 \\
\hline No idea & 1 \\
\hline Total & $\mathbf{2 2}$ \\
\hline
\end{tabular}

Source: Field data 2019

\subsection{Effects of Climate Change in Barotse Floodplain}

The study reviewed several effects of climate change in the Barotse floodplain (Table 3)

Table3: Responses on the Effects of climate change

\begin{tabular}{|l|}
\hline \multicolumn{1}{|c|}{ Responses } \\
\hline -
\end{tabular}


- $\quad$ Reduction or low yields in crop harvest like maize and rice

- Low food production due to drought

- Disappearance of some animal species such as $\mathrm{Ng}$ 'otwatuya (imaginary river monster) and Situtunga (water buck)

- Excessive temperatures in the floodplain than before

- Floods leading to crop damage

- Low milk production

- Outbreak of dieses in animals such as foot and mouth disease

- Reduction in some plant species like Linjefu (water nutof an aquatic plant)as well as Mashela and Mampana which are both edible tuberous plants.

- Reduction in cattle population due to excessive heat

- Lack of animal pastures due to drought

Source: Field data: 2019

\subsection{The Adaptation Practices of the Local Communities in Barotse Floodplain}

Some of the adaptation measures practiced in the Barotse floodplain according to the study is shown in Table 4.

Table4: Responses on the adaptation measures practiced in Barotse floodplain

- Using man'ele (ligneous grass), linjefu ( water nut fruit of an aquatic plant) mashela ( edible tuberous plant of the water lily family) and mambumbwe (ligneous grass)as firewood as this discourages deforestation

- Growing drought resistance crops like early maturing cassava locally known as lipuu which is grown in fields called matongo. It is usually planted in June and harvested in December.

- Growing of vegetables in fields locally called litapa

- Intensifying fishing though water levels are low

- Seasonal movement of cattle from the floodplain to the upper land when the plain is flooded and only returns when water levels are low. This movement of animals allows pastures to regenerate before the animals come back to the plain.

Source: Field data, 2019

\subsection{Climate Change Education Awareness Activities Taking Place in Barotse Floodplain}

The study showed very little climate change awareness activities taking place in the area. Out of the 22 respondents interviewed in Barotse floodplain, 18 said there were no climate change activities taking place in the area (Table 5). Only 3 said there were climate change activities taking place in the area (Table 5). This activity was only conducted in Lealui village. The study revealed that the climate change awareness was related to fish farming. The local community in Lealui were taught the skills of fish farming by a Non-Governmental Organisation based in Mongu town called Mumwaa craft centre.

Table5: Response as to whether there are climate change awareness activities taking place in Barotse floodplain

\begin{tabular}{|l|l|}
\hline \multicolumn{1}{|c|}{ Response } & \multicolumn{1}{c|}{ Frequency } \\
\hline YES & 3 \\
\hline NO & 19 \\
\hline No idea & 0 \\
\hline Total & $\mathbf{2 2}$ \\
\hline
\end{tabular}

Source: Field data 2019

\section{DISCUSSION}

The aim of the study was to find out how communities in the Barotse floodplain of Mongu district are affected by climate change and established adaptation opportunities practiced by the inhabitants of the area. The study further investigated climate change awareness activities in the area.

\subsection{Effects of Climate Change Experienced in Barotse Floodplain}

The study revealed several effects of climate change experienced in the Barotse floodplain ranging from reduction in crop harvest to depletion and disappearance of some plant and animal species. The study indicated excessive heat in the plain which has consequently led to reduction in food production 
and security in Barotse floodplain. Low yields in crops like maize (Zea mays) and rice (Oryiza sativa) have been experienced in the area as a result of excessive temperatures leading to drought.

Furthermore, the climate change effects experienced in Barotse floodplain has led to depletion of some animal water buck locally known as Sitatunga (water buck),, fish like dona fish, and bird species such as open Nongolo (open- bill stock), Machikwi (spur - winged goose), Miombo (Marabou stock), Kanu'umbi (cormorantspp) and Mulindeti (snake bird).Disappearance of some animal species such as $\mathrm{Ng}$ 'otwatuya (imaginary aquatic or river monster) which was believed to be responsible for eroding river banks. The study further revealed climate change effects in Barotse floodplain has led to extinction of some plants birds and animal species such as such as Situtunga (water buck) and reptiles such as Lingongole (huge imaginary water snake) that was believed to be responsible for deepening and widening of the Zambezi river locally referred to as Liambai. These species are no longer seen in Barotse floodplain. Some of the plant species rarely found in Barotse floodplain includes species like Linjefu (water nut fruit of an aquatic plant), Mashela (edible tuberous plant of the water lily family), Situtu (grass species) and Mampana (edible aquatic tuberous plant).

In addition, climate change effects in Barotse floodplain has led to, excessive flooding plain and prolonged spells of unexpected changes in seasons in the area. The effects of climate change such as have led to reduction in animal pastures in the floodplain and consequently reduced cattle population in Barotse floodplain. Milk production has also been affected in the area. Outbreak of diseases such as foot and mouth disease locally known as nyoko was also prevalent in the floodplain. The prevalent of the outbreak is attributed to excessive heat currently experienced in the area.

\subsection{Adaptation Opportunities Practiced by the Lozi People in Barotse Floodplain in Mitigating Climate Change Effects}

The Lozi people in Barotse floodplain in Zambia practice certain ecological knowledge that helps them cope with the effects of climate change. Some of these adaptation practices include the following:

\subsection{Seasonal Movement of Cattle}

The Lozi people of Barotse floodplain practice seasonal movement of their cattle, a practice locally has known as "kufuluhela" from the Barotse floodplain to the upper land when the floodplain is flooded (Moonga and Milupi 2015). The animal only returns to the floodplain when water levels are low. This ecological knowledge of animal movement practiced by the Lozi people allows pastures to regenerate before the animals are taken back to the floodplain (Moonga and Milupi, 2015).

\subsection{Using Other Sources of Firewood}

The use of alternative sources of firewood such as the use of man'ele (ligneousgrass), mashela (edible tuberous plant of the water lily family), linjefu (water nut fruit of an aquatic plant), mambumbwe (singular limbumbwe)a ligneous grass used as fuel and masu (dry cow's dung also used as fuel by malozi). As observed by Milupi et al., 2017, the use of these alternative sources of fuel by the Lozi people in Barotse floodplain promotes sustainable utilization of natural resources and hence reduces the effects of climate change currently experienced in the area. Another conservation measure commonly practiced by the Lozi speaking people of Barotse floodplain is the one locally referred to as Kutulisa. This is the practice where cattle are not allowed to graze on the same place for an extended period of time. The practice has the effect of preventing soil degradation.

\subsection{Growing of Early Maturing Crops}

Growing drought resistance crops like early maturing cassava locally known as lipuи in Barotse floodplain is also common in the area. This type of cassava is grown in fields locally called matongo. It is usually planted in June and harvested in December. Matongo (plural of "litongo") are rarely flooded landforms often found at the margins of the Borotse floodplain.

Vegetables are also grown in fields locally known as litapa. Litapa (plural of "Sitapa") represent landforms on which annual flooding of the floodplain deposits silt and humus from vegetation and decaying aquatic plants. These deposits enrich the fertility of the land on the plains, creating fertile arable land for crop production. The growing of vegetables is also done on fields locally known as "Mazulu" (plural of "lizulu"). These fields consist of landforms raised above the general floodplain 
level. They have some of the best soils in the floodplain. However, they are also exposed to risks from flooding and drought, and some are left fallow due to their isolation.

\subsection{Climate Change Awareness Activities in Barotse Floodplain}

Climate change awareness and education are key in climate change mitigation and adaptation. The study however showed very little climate change awareness activities taking place in Barotse floodplain. Most of the respondents (18) out of the 22 respondents (Table 5) said there were no climate change activities taking place in the area. Only 4 out of 22 respondents indicated some awareness activities in the area. Fish farming according to the study was the only climate change awareness activity that was done with the local people of Lealui in the floodplain by Mumwa craft centre, a Non-Governmental Organisation (NGO) based in Mongu town.

\section{CONCLUSION}

The study revealed several effects of climate change in Barotse floodplain. These effects ranged from, reduction in crop harvest, depletion of some animal and plant species as well as disappearance of some plant and animal species. The study also revealed vast local ecological knowledge prevalent among the Lozi people of Barotse floodplain that were employed in order to mitigate and adapt to the effects of climate change in the area. This range of LEK, if utilised in climate change mitigation and adaptation could Foreseeably encourage greater involvement of local communities in management of climate change to enhance environmental sustainability in the area. The diverse LEK systems identified in the study carry strong conservation messages and could all be used as entry points into sustainable climate change management. It is further recommended that policy makers consider including the use of LEK in the mitigation and adaptation measures of climate change. Furthermore, the study showed inadequate climate change awareness and education activities in the Barotse floodplain. We strongly propose that the government and other stakeholders dealing in climate change issues put in place awareness programmes for the local people in order to enhance their knowledge.

\section{RECOMMENDATIONS}

There is need for more climate change awareness programmes to be conducted in Barotse floodplain by Government and some nongovernmental organisations that deal with climate change issues. This is because the climate change awareness programmes would help the communities to understand and address the impacts of climate change in the area. The activities would further promote attitude and behaviour change required for the sustainable use of natural resources.

\section{ACKNOWLEDGEMENT}

We would like to thank the local communities' in the various villages visited in the Barotse floodplain for making themselves available for interviews. We also acknowledge the efforts of our colleague Mwakoi Patricia for providing us with a Lozi to English dictionary.

\section{REFERENCES}

[1] Baidu-Forson, J.J., Phiri, N., Ngu'ni, D., Mulele, S., Simainga, S.,Situmo, J., Ndiyoi, M., Wahl, C., Gambone, F., Mulanda, A., Syatwinda, G. (2014). Assessment of agrobio diversity resources in the Barotse floodplain, Zambia. CGIAR Research Program on Aquatic Agricultural Systems. Penang, Malaysia. Working Paper: AAS-2014-12.

[2] GRZ, (2014).Environmental and social impact assessment for the improved use of priority traditional canals in the Barotse sub-basin of the Zambezi. BRM and NIRAS, V3, Final Report

[3] IPCC, (2007a): Climate Change 2007.Impacts, Adaptation and Vulnerability. Cambridge: Cambridge University press.

[4] IPCC, (2007b): Climate Change: Synthesis Report. Contribution of Working Groups I, II and III to the Fourth Assessment Report of the Intergovernmental Panel on Climate Change. Geneva: Intergovernmental Panel on Climate Change.

[5] McSweeney, C., New, M. and Lizcano, G. (2010).UNDP Climate Change Country Profiles: Zambia. Accessed July 2019, at http:// country-profiles.geog.ox.ac.uk. 
[6] Milupi, I., Somers, M., and Ferguson, W. (2017). Local ecological knowledge and community based management of wildlife resources: A study of the Mumbwa and Lupande Game Management Areas (GMAs) of Zambia. South African Journal of Environmental Education, 33, 25-38. https://doi.org/10.43 14/sajee.v.33i1.3

[7] Milupi, I. D, Somers, M.J, and Ferguson, W. (2019). Inadequate community engagement hamstrings sustainable wildlife resource management in Zambia, African Journal of Education. DOI: 10.1111/aje. 12685

[8] MLNREP (Ministry of lands and Natural Resources and Environmental Protection) (2016). National Policy on Climate Change, Lusaka, Zambia, Ministry of lands and Natural Resources and Environmental Protection

[9] Moonga, M. and Milupi, I. (2015).Transmission mechanisms of local ecological knowledge in Zambia: The case of the Lozi speaking people of Western Province. Research paper presented at the 5th African RCE Conference, Entebbe, Uganda. Https://www.rcenetwork.org Retrieved $1^{\text {st }}$ August, 2019

[10] MTENR (Ministry of Tourism and Natural Resources),(2010).National Climate Change Response Strategy. Zambia Ministry of Tourism, Environment and Natural Resources. http://www4.unfccc.int/nap/ Documents/Zambia\%20Climate\%20Change\%20Response\%20Strategy.pdf

[11] NPCC, (National Policy on Climate Change), (2016).Ministry of Lands, Natural Resources and Environmental Protection.

[12] Nhemachena, C. (2009).Agriculture and Future Climate Dynamics in Africa: Impacts and Adaptation Options. Pretoria: University of Pretoria.

[13] Nicholls, J. (2016):Understanding how Queensland teachers' views on climate change and climate change education shape their reported practices. Doctoral Dissertation. Cairns, Australia:James Cook University.

[14] Nkhata, D. and Kalumiana,O (1997). Energy Needs and Shortfall Assessment of the Barotse floodplain of Western Province, IUCN - The World Conservation Union Regional Office for Southern Africa, Harare

[15] Nyanga, H., Johnsen, H., Aune, B and Kalinda, H.T (2011).Smallholder Farmers' Perceptions of Climate Change and Conservation Agriculture: Evidence from Zambia, Journal of Sustainable Development Vol. 4, No. 4

[16] Oxfam, (2015). The Zambia country report, Climate Change Adaptation Finance in Zambia: A Call to Transparency and Accountability, Zambia Climate Change Network and Caritas Zambia for the Adaptation Finance Accountability Initiative (AFAI)

[17] Owen, G.T. (2014). Qualitative methods in higher education policy analysis: Using interviews anddocument analysis. The Qualitative Report, 19(26), 1-19.

[18] Pouliotte, J., Smit, B., and Westerhoff, L. (2009). Adaptation and development: Livelihoods and climate change in Subarnabad, Bangladesh. Climate Change and Development, 1, 31-46. doi:10.3763/cdev.2009. 0001,http://dx.doi.org/10.3763/cdev.2009.0001

[19] Romdhani, A., CollBesa, M., Scott, D. and Bharwani, S. (2018).Zambia's adaptation to climate change

[20] Simwinji, N. (1997).Summary of Existing Relevant Socio-Economic and Ecological Information on Zambia's Western Province and Barotseland, IUCN - The World Conservation Union Regional Office for Southern Africa, Harare.

[21] Timberlake, L. (1997). Biodiversity of the Zambezi Basin Wetlands: a Review of Available Information, Zambezi Society and Biodiversity Foundation for Africa Report to IUCN - The World Conservation Union Regional Office for Southern Africa, Harare.

[22] Turpie, J. Smith, B., Emerton, L., and Barnes, J. (1999).Economic value of the Zambezi Basin wetlands. Zambezi Basin Wetlands Conservation and Resource Utilization Project, IUCN Regional Office for Southern Africa. The Canadian International Development Agency (CIDA).Printed by University of Cape Town.

[23] UNESCO,(2009).Learning to Mitigate and Adapt to Climate Change: UNESCO and Climate Change Education. Retrieved from http://unesdoc.unesco.org on $15^{\text {th }}$ July, 2019

\section{AUTHORS' BIOGRAPHY}

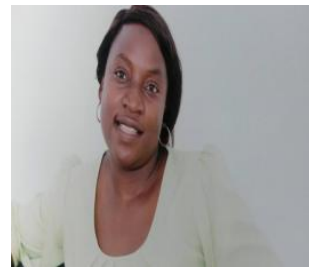

Inonge Milupi D. (PhD) is a lecturer and researcher of Environmental Education at the University of Zambia. Her research interest includes climate change, environment and society as well as indigenous Knowledge. 


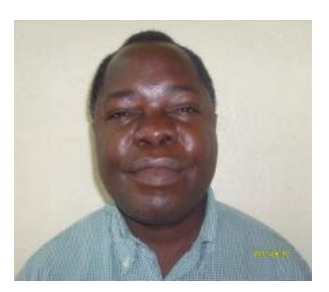

Charles M. Namafe is currently Associate Professor of Environmental Education in the School of Education at the University of Zambia. His research interests include among others climate change and floods.

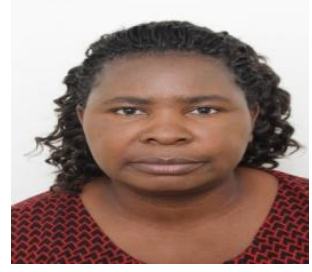

Mirriam Sampa Moonga is a lecturer/researcher and a $\mathrm{PhD}$ student of Environmental Education at the University of Zambia. Her research interests include Education for Environmental Sustainability, climate change and traditional/indigenous knowledge.

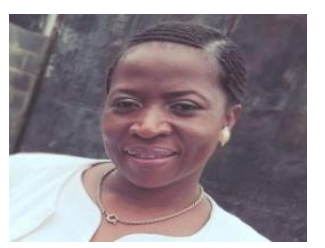

Njungu Mwimanenwa is a Lecturer/ Researcher at Copperbelt University and a $\mathrm{PhD}$ student at the University of Waterloo in Canada. Her research interests include impacts of extreme weather events (especially floods) on access to maternal and child health services.

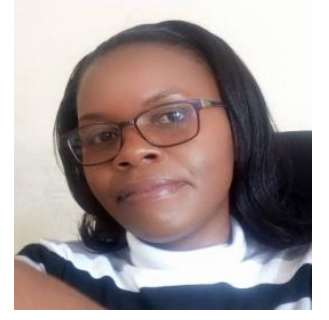

Pauline Monde, $\mathbf{N}$. is a lecturer/researcher and a PhD student of Environmental Education at the University of Zambia. Her research interests include Environmental Governance and management.

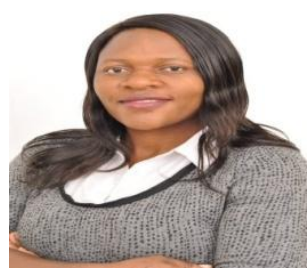

Simooya Steriah is a lecturer and researcher of Environmental Education at the University of Zambia. Her research interests include Environmental Journalism and Economics.

Citation: Milupi, I. D, Njungu, et.al. "Climate Change Impacts, Vulnerability, and Adaptation Options among the Lozi Speaking People in the Barotse floodplain of Zambia". International Journal of Humanities Social Sciences and Education (IJHSSE), vol.6, no.9, 2019, pp. 149-157. doi: http://dx. doi.org/10.20431/ 2349-0381.0609017.

Copyright: (C) 2019 Authors. This is an open-access article distributed under the terms of the Creative Commons Attribution License, which permits unrestricted use, distribution, and reproduction in any medium, provided the original author and source are credited. 